\author{
Emilia Wieliczko-Paprota (iD) https://orcid.org/0000-0001-8662-6490 \\ Uniwersytet Gdański \\ emiliawieliczko@wp.pl
}

\title{
Subtelna subwersywność kobiecego ciała w extravaganzach J.R. Planchégo
}

\section{The Subtle Subversiveness of the Female Body in J.R. Planche's Extravaganzas}

\begin{abstract}
This article takes up the problem of the subversive contents in the extravaganzas of James Robinson Planché, a dramatist and creator of popular theatre in Victorian England. The female body of the extravaganzas is unlike that encountered in bodily visions imposed by the rigorous etiquette of the puritanical society of nineteenth-century England. The analysis is primarily focused on those phenomena wherein the female body is undergoing constant transformation, being contextualized and shaped in accordance with the laws of a dominant culture. It is posited that the extravaganzas created for Easter and Christmas played the role of carnival, that is a time when it was permitted to present the world in reversal, and to speak against the dominant gender discourse. In Planché's plays the female body is constructed in a space between the audience, the actor, the word, and theatre. It is a "body-in-between," a living space of dialogue, a playing field of the dominant discourse and the subversive consciousness. The female body is both strange to the onlooker as well as untamed by the actors, who are only partially capable of controlling the ultimate form of their body on the stage. The substance of theatre represented by the physical matter of the body, turns out to be a dynamic form emerging from the inscriptive gaze, the contents of the play, and the attributes of the theatrical space itself.
\end{abstract}

Keywords: extravaganza, body, theatre, subversiveness, performativity

Streszczenie: Artykuł porusza problem subwersywnych treści extravaganz Jamesa Robinsona Planchégo, dramatopisarza i twórcy teatru popularnego wiktoriańskiej Anglii. W extravaganzach wizerunek kobiecego ciała daleki jest od cielesnych wizji podyktowanych przez rygorystyczną etykietę pruderyjnego społeczeństwa dziewiętnastowiecznej Anglii. Analiza skupia się przede wszystkim na treściach, w których kobiece ciało ulega ciągłym transformacjom, jest kontekstualizowane i formowane według praw dominującej kultury. Postawiono tezę, iż extravaganza pisana na potrzeby Świąt Wielkanocnych i Bożego Narodzenia odgrywała funkcję karnawału, w którym folgowano potrzebie przedstawiania świata na opak i pozwalano zaistnieć głosowi przemawiającemu przeciwko dominującemu dyskursowi płci. W sztukach Planchégo ciało kobiece formuje się między przestrzenią widowni, 
aktora, słowa i teatru. Jest to „ciało-pomiędzy”, żywy obszar dialogu, pole rozgrywki między dominującym dyskursem a subwersywną świadomością. Kobiece ciało jest tu zarówno obce dla oczu widza, jak i nieoswojone przez aktorów, którzy tylko częściowo mogą zapanować nad ostateczną formą swojego ciała na scenie. Substancja teatru, jaką jest fizyczna materia ciała, okazuje się dynamiczną formą wynikającą z inskrypcji spojrzeń, treści dramatu i atrybutów teatralnej przestrzeni.

Słowa kluczowe: extravaganza, ciało, teatr, subwersywność, performatywność

\section{Współczesna walka o wiktoriańską kobiecość}

Wizerunek idealnej wiktoriańskiej kobiety jako anioła domowego ogniska, strażniczki moralności i przewodniczki upadłych męskich dusz jest silnie zakorzeniony w świadomości współczesnych odbiorców epoki. Jednak anioły rodem z poematu Coventry Patmore'a Angel in the House są tylko złudą naszego wyobrażenia o tamtych czasach. Poddańczą duszę ideału wiktoriańskiej damy zabiła już Virginia Woolf w roku 1931, wygłaszając przemówienie o pracach zawodowych kobiet, udaremnianych przez zjawę Anioła Domowego Ogniska: „To ona stawała między mną a arkuszem papieru, kiedy siadałam do pisania recenzji. Ona mnie prześladowała, marnowała mój czas i dręczyła mnie tak, że w końcu postanowiłam, że ją zamorduję" ${ }^{1}$. Ta symboliczna śmierć zapoczątkowała nową historię wiktoriańskiej kobiecości, chociaż kulminacja tych tendencji interpretacyjnych przypada dopiero na lata osiemdziesiąte. Wtedy wraz z drugą falą feminizmu zaistniała potrzeba odczarowywania fałszywych stereotypów. Joan Wallach Scott w artykule Gender: A Useful Category of Historical Analysis ${ }^{2}$ pisała w tamtym okresie o potrzebie nowej metody badań historycznych, w których kategoria płciowości byłaby nadrzędną siłą sprawczą historii. Opierając się na filozofii Michela Foucaulta, Scott twierdzi, iż historia jest niczym więcej, jak tylko walką o kontrolę nad ciałem. Płeć natomiast stanowi pole, na którym ta walka się toczy. Badacz powinien więc się przyjrzeć strukturom społecznym, takim jak rodzina, klasa, miejsca pracy, ośrodki edukacji, by móc dokonać analizy żeńskich i męskich relacji oraz ich walki o dominacje. W związku z zapotrzebowaniem, o jakim pisała Scott, pojawiło się wiele prac, które odkrywały kobiety w historii i dla historii na nowo, przełamując bariery uniemożliwiające udział płci żeńskiej w kształtowaniu rzeczywistości historycznej. Dzieła

${ }^{1}$ V. Woolf, Praca zawodowa kobiet [w:] tejże, Eseje wybrane, wybór, oprac. M. Heydel, R. Sendyka, przeł. M. Heydel, Kraków 2015, s. 278.

2 J.W. Scott, Gender: A Useful Category of Historical Analysis, „American Historical Review" 1986, nr 91 (5). 
Nancy Armstrong ${ }^{3}$, Mary Poovey ${ }^{4}$, Elizabeth Langland ${ }^{5}$ dotyczące dziewiętnastowiecznej Anglii przyczyniły się do zmiany w myśleniu o kobiecie wiktoriańskiej. Podkreślały jej żywy udział w tworzeniu tożsamości klasowej, napędzaniu kapitalistycznej maszyny biznesu, oraz w powstawaniu imperialistycznego wizerunku narodu. Jednak, jak wskazuje Amanda Anderson ${ }^{6}$, pozycje wymienione powyżej, oraz (choć w mniejszym stopniu) praca Leonore Davidoff i Catherine Hall ${ }^{7}$ tylko pozornie wyzwalają kobiety wiktoriańskie spod jarzma bierności. Kobiety dziewiętnastego wieku wraz z drugą falą feminizmu niezaprzeczalnie urosły w siłę, zostały jednak pozbawione samokrytyki oraz świadomości posiadania władzy i celowego jej reprezentowania. Amanda Anderson proponuje analizę stanów świadczących o świadomym uczestnictwie w kulturze i historii, co możliwe jest wyłącznie w momentach oddalenia, zdystansowania czy odłączenia się od dominującego dyskursu. Dialog z rodzimą kulturą, dający świadectwo oderwania się od własnych korzeni, jest jednak uchwytny tylko w obszarze historii indywidualnej. Trudno bowiem przedstawić moment zdystansowania całej grupy społecznej, klasy czy narodu od nadrzędnej ideologii. Możliwa jest jednak próba połączenia jednostkowego dialogu ze społeczną postawą wobec płci żeńskiej, jeśli indywidualny dyskurs odbywa się w trakcie masowego wydarzenia. $Z$ taką sytuacją mamy do czynienia w polemice Jamesa Robinsona Planchégo z patriarchalną wizją społeczeństwa, która odbyła się w wiktoriańskim teatrze popularnym. Planché był sławnym dziewiętnastowiecznym dramaturgiem, reżyserem i kostiumologiem. Odegrał on ważną rolę w kształtowaniu angielskiej komedii muzycznej, będąc autorem lub współtwórcą ponad 176 sztuk, które ukonstytuowały wiktoriański teatr popularny. Agnieszka Jelewska-Michaś w zbiorowej pracy poświęconej teatrowi masowemu zauważa, iż żaden teatr ani wcześniej ani później nie dorównał teatrowi wiktoriańskiemu w popularności i powszechności odbioru ${ }^{8}$. Autorka Wiktoriańskiego modusu melodramatycznego zwraca uwagę, iż nie sama liczba świadczyła o niezwykłości teatru tamtych czasów, a specyficzna relacja teatru z rzeczywistością pozasceniczną, w której formy dramatyczne stały się kluczem odczytywania świata i językiem komentującym współczesne wydarzenia. Jednocześnie Lynn

${ }^{3}$ N. Armstrong, Desire and Domestic Fiction: A Political History of the Novel, New York 1987.

${ }^{4}$ M. Poovey, Uneven Developments: The Ideological Work of Gender in Mid-Victorian England, Chicago 1988.

5 E. Langland, Nobody's Angels: Middle-Class Woman and Domestic Ideology in Victorian Culture, London 1995.

${ }^{6}$ A. Anderson, The Powers of Distance: Cosmopolitanism and the Cultivation of Detachment, Princeton 2001, s. 36.

7 L. Davidoff, C. Hall, Family Fortunes: Men and Women of the English Middle Class 1780 1850, New York 1987.

${ }^{8}$ A. Mielewska-Miachaś, Wiktoriański modus melodramatyczny $w$ kontekście teatru masowego epoki [w:] Teatr masowy - teatr dla mas, red. M. Leyko, Łódź 2011, s. 151. 
M. Voskuil podkreśla istotę kierunku odwrotnego, w którym to rzeczywistość znajdowała odzwierciedlenie w teatrze i współtworzyła świat sceniczny9. Ścisły związek między tymi dwoma światami, żywa reakcja publiczności oraz zaangażowanie przyczyniły się do stworzenia namiastki demokratycznego panelu dyskusyjnego. Widownia tworzyła swoisty zbiór ludzi różnych środowisk, zjednoczonych na potrzeby spektaklu, gdzie wszyscy mieli prawo oglądać, przeżywać i komentować współczesność pozateatralną. Oczywiście, jak pisze Russell Jackson, relacja między różnymi klasami w teatrze wiktoriańskim nie była prosta, tworzyła jednak mniej lub bardziej zjednoczoną grupę odbiorców współodczytującą rzeczywistość ${ }^{10}$. Mielewska-Michaś pokusiła się wręcz o śmiałą tezę, iż demokratyzm społeczny w teatrze zapobiegł rewolucji społecznej, tak popularnej w Europie tamtych lat ${ }^{11}$. Podobnego zdania jest David Mayer, który pisze, iż melodramat pozwolił złagodzić główne konflikty biorące się z burzliwych przemian wieku dziewiętnastego ${ }^{12}$. Dyskusja na temat industrializacji, urbanizacji, kryzysu w rolnictwie, biedy i budzących się do życia nowych form wypowiedzi społecznej oraz debata o rolach płci pojawiły się w teatrze pod maską sensacji, efektów i śmiechu. Fiona Macintosh słusznie zwraca uwagę, iż zanim pod koniec wieku pojawiły się Nowa Kobieta i ruch sufrażystek, świadomość społeczną dotyczącą płci żeńskiej kształtował teatr burleskowy, pantomimiczny czy extravaganze ${ }^{13}$. Kobiety tych form teatralnych epatowały tym, co Maria Elena Buszek nazwała awarishness, czyli samoświadomością seksualną:

Jednak zanim Nowe Kobiety były w stanie wyartykułować i głośno wypowiadać swoje żądania, w celu przekroczenia binarnego światopoglądu, który naznaczał kobiecą tożsamość w społeczeństwie; w teatrze wielopostaciowa, zmieniająca się, wręcz niestabilna kobiecość aktorki była nie tylko akceptowaną, lecz także oczekiwaną osobowością kobiety ${ }^{14}$.

W extravaganzach Planchégo kształtowanie kobiecości odpowiadało tym ogólnospołecznym nastrojom wymierzonym przeciwko patriarchalnej wizji świata, w której kobieta stanowiła jednowymiarowy obraz uległości i beznamiętności. Jego sztuki skierowane przede wszystkim do klas średnich i arystokracji

9 L.M. Voskuil, Acting Naturally: Victorian Theatricality and Authenticity, Charlottesville 2011, s. 62.

${ }_{10}$ R. Jackson, Victorian Theatre: The Theatre in Its Time, London 1989, s. 29.

11 A. Mielewska-Michaś, dz. cyt., s. 152.

${ }^{12}$ D. Mayer, Encountering Melodrama [w:] The Cambridge Companion to Victorian and Edwardian Theatre, red. K. Powell, Cambridge 2004, s. 146.

${ }_{13}$ F. Macintosh, Medea Transposed: Burlesque and Gender on the Mid-Victorian Stage [w:] Medea in Performance 1500-2000, red. E. Hall, F. Macintosh, O. Taplin, Oxford 2000, s. 75.

${ }^{14} \mathrm{~W}$ tekście artykułu znajdują się tłumaczenia z języka angielskiego dokonane przez autorkę pracy. M.E. Buszek, Pin-Up Grrrls: Feminism, Sexuality, Popular Culture, Durham 2006, s. 28. 
uderzały w główne wartości tych klas, zależne jednak od popularności i finansów widowni, nie dążyły do rewolucji społecznej. Planché, autor i reżyser własnych dramatów, konstruował swoje bohaterki wokół społecznie akceptowalnych wizerunków kobiecości, wplatając subwersywność ich charakteru w łagodny świat pełen poetyckiej gracji i fantazji. Transformacje jego kobiecych postaci, dalekie od patriarchalnych wzorców, unaoczniają zmianę w myśleniu o płci żeńskiej i kobiecym ciele. Popularność jego sztuk świadczy o nawiązaniu dialogu społecznego z obowiązującymi normami paternalistycznej rzeczywistości.

\section{Inskrypcje na ciele w extravaganzach Jamesa Robinsona Planchégo}

Hans-Thies Lehmann pisze, iż dopiero modernizm przyniósł teatrowi ciało bez znaczeń naddanych, ciało nagie w swej prawdzie, epatujące erotyką, krwią i flegmą ${ }^{15}$. Przed tym okresem, pisze autor Postdramatycznego teatru, ciało wnosiło na scenę inne znaczenia niż sama cielesność. Jednak teatr popularny w formach pantomimicznych, burleskowych czy właśnie extravaganzach był bliski modernistycznej wizji, dotyczył bowiem seksualności, wyglądu i roli społecznej ciała. W extravaganzach J.R. Planchégo teatr dzieje się nie tylko między ciałami, ale także na nich i w ich obrębie. Ciało jest niezaprzeczalną substancją tego teatru, formowaną przez wzrok widza, świadomość aktora, tekst sztuki i materię teatru. Niemniej w wieku dziewiętnastym ciało, a szczególnie ciało kobiece, nie było jeszcze odrębnym bytem, epatującym obcością i abiektem, który według myśli Julii Kristevej symbolizuje wszystko to, co z ciała wychodzi i zostaje przez nas odrzucone ze wstrętem, a co modernizm manifestował na deskach teatru ${ }^{16}$. Cielesność dziewiętnastowieczna walczyła dopiero o autonomię, prawo do samookreślenia i swobodę przedstawiania. Teatr popularny epoki wiktoriańskiej pozostał w pewnym stopniu wojerystyczny, tak więc ciało wnosiło do sztuki znaczenia spoza teatru. Inga Iwasiów zauważa, iż w teatrze tamtych czasów patriarchalny widz narzucał na ciało kobiecy kod, wedle którego odczytywał swoje pożądanie, przez co było ono najczęściej obiektem określanym przez dostępny publiczności język erotyczny ${ }^{17}$. Tracy Davis w Actress as Working Women roztacza przed czytelnikami zbiór kontekstów, według których męski widz

15 H.T. Lehmann, Postdramatic Theatre, New York 2006, s. 162.

${ }^{16}$ J. Kristeva, Powers of Horror: An Essay on Abjection, New York 1982, s. 32.

17 I. Iwasiów, Między queer a zwyktościa. Pożądanie (na) spektaklu [w:] Inna scena: ciato, pteć, pożądanie. Tożsamość seksualna i tożsamość ptci w polskim dramacie i teatrze, red. A. Adamiecka-Sitek, D. Buchwald, Warszawa 2008, s. 37. 
odczytywał kobiecość w teatrze ${ }^{18}$. Widz podglądał aktorki, ubierał je w swoje wizje, pragnienia i formował ciało performerki swoim wzrokiem. Extravaganze Planchégo odzwierciedlają to społeczne zapatrywanie na płeć, ciało kobiece jest tam bowiem stworzone z pragnienia tłumu, z lęków, ze społecznej świadomości jego roli. Jednocześnie subwersywność tej formy teatralnej konfrontuje widza z niepewnością co do statusu, norm i praw kształtujących cielesność, inicjując nowy dyskurs dotyczący kobiecego ciała i dekonstruując stereotypowe kategorie.

Subwersywność extravaganz była możliwa dzięki medium, jakim była gra aktorska. G. Rodosthenous we wstępie do książki poświęconej przyjemności patrzenia w teatrze, pisze, iż teatr nigdy nie jest do końca wojerystyczny, gdyż spektakl rodzi się między odbiorcą a aktorem, który odpowiada na wzrok widza $^{19}$. W sztukach Planchégo aktor zaś był niezwykle ważny. Wiele jego dzieł powstało dla Madame Elizabeth Vestris, najpopularniejszej aktorki tamtych czasów i pierwszej w historii Anglii menadżerki własnego teatru. Jak zwraca uwagę Jane Moody, prawdopodobnie aktywność tej aktorki w budowaniu spektakli nie ograniczała się do odgrywania w nich ról ${ }^{20}$. Liczne odniesienia do jej personalnej biografii wskazywać mogą, iż współtworzyła ona sztuki odgrywane w jej teatrze. Trudno sobie zresztą wyobrazić, iż władcza i nieugięta menadżerka Olympic Theatre, autokratycznie rządząca swoim teatrem, nie miałaby wpływu na treść przedstawień reprezentujących ją i jej scenę. Elizabeth Vestris była sławna z świadomego kreowania swojego wizerunku, była boginią sceny i erotyczną ikoną kobiecego ciała. Jak pisze Gary Jay Williams, role Madame Vestris zaprzeczają współczesnym interpretacjom, przypisującym męskiej widowni tamtych czasów pozycję gapiów uprzedmiatawiających kobiece ciało ${ }^{21}$. Vestris przekształcała widownie w wojerystyczny tłum, narzucając mu jednak nowy wizerunek kobiecości: z jednej strony eteryczny, anielski z drugiej zaś pociągający i dominujący. James Robinson Planché w tekstach pisanych dla jej teatru obrazował to pełne sprzeczności kobiece ciało, które podlegało ciągłym transformacjom, umykało jednoznacznym interpretacjom, wydawało się bezkształtne, czasami poćwiartowane, skłonne do re-figuracji i metamorfoz. Co więcej, ciało to było ciągle kształtowane przez współczesną kulturę i politykę. Sztuka Olympic Revels z Madame Vestris w roli głównej otworzyła Olympic Theatre, inicjując subwersywny charakter całej późniejszej współpracy Vestris i Planchégo. Autor extravaganzy sięga w niej do mitu o stworzeniu Pandory. Jest to

18 T. Davis, Actress as Working Women: Their Social Identity in Victorian Culture, New York 1991.

19 G. Rodosthenous, Introduction [w:] Theatre as Voyeurism: The Pleasure of Watching, red. G. Rodostenous, London 2015, s. 4.

${ }^{20}$ J. Moody, Illusions of Authorship [w:] Women and Playwriting in Nineteenth-Century Britain, red. T.C Davis, E. Donkin, Cambridge 1992, s. 102.

${ }^{21}$ G.J. Williams, Our Moonlight Revels: A Midsummer Night's Dream in the Theatre, Iowa City 1997, s. 97. 
jeden z najbardziej znanych mitów reprezentujących kobietę jako niewolnika swojej seksualności i tłumaczących jej pozycje społeczną pierwotnym grzechem. Stwarzanie Pandory jest w Olympic Revels aktem formowania kobiety współczesnej, na której ciele zapisywane są normy wiktoriańskiego świata. Obnażony tu zostaje mechanizm nadawania kształtu kobiecie i urabiania jej ciała przez patriarchalny świat bogów. Angelina Poon zwraca uwagę, iż imperialistyczna angielskość była przede wszystkim konstruowana wokół idealnego ciała: białego, heteroseksualnego, produktywnego i wyzutego z cielesności ${ }^{22}$. Zarówno książki dla chłopców, jak i podręczniki dla kobiet miały formować idealny kształt narodu angielskiego, odnosząc się przede wszystkim do praw, obowiązków i zakazów dotyczących ciała. Odpowiednio profilowane ciała stawały się nośnikiem inskrybowanych na nich znaczeń, wartości i praw. Jednocześnie dziewiętnastowieczne ciało przestało odtwarzać model renesansowego człowieka, w którym cielesność ubrana i rozebrana oznaczała fałsz i prawdę. Zjednoczenie nagiego ciała z ubranym lokowało jego prawdę poza empiryczną biologią ${ }^{23}$. Erotyka, seksualność i sens ciała stały się grą między właścicielem i świadomością odbiorcy. Dziewiętnasty wiek zapoczątkował rewolucję w myśleniu o człowieku, terminy „rzeczywisty” czy „faktyczny”, a co za tym idzie - „naturalny” i „neutralny” stały się fantazmatem spełniającym funkcje pozornej, lecz bezpiecznej substancjalności. Ciało, jego płeć, znaczenie i świadomość cielesności rodziło się w akcie inskrypcji wartości na ciele-odbiorcy. Nieustannie nakładane na siebie warstwy znaczeń i wpływów tworzyły ciała skomplikowane, dynamiczne, płynne, często momentalne, dalekie od kartezjańskiego dualizmu. Rezultatem takiego zapisywania, urabiania i podlegania inskrypcji jest Pandora, grana przez Madame Vestris, w sztuce Planchégo. Świadczy o tym rozmowa między Jupiterem i bogami:

Jup. W istocie bardzo zręczna praca synu V., Tak żywa jak wszystko, co żyje.

Vul. Nie mnie śpiewać peany na swój temat

Lecz mogę powiedzieć (...)

Widziałem gorsze.

Jup. Gorsze? Ja nigdy nie widziałem lepszej.

Zastosowałeś się do instrukcji co do joty.

(...)

Teraz żądam wszystkich waszych mocy jako podarunków,

Wy bóstwa, ozdóbcie tą wykwintną panią.

Pozwólcie Miłości zacząć, i jego subtelną strzałą

22 A. Poon, Enacting Englishness in Victorian Period: Colonialism and Politics of Performance, New York 2008, s.16.

${ }^{23}$ Zob. C. Finch, "Hooked and Buttoned Together”: Victorian Underwear and Representations of the Female Body, „Victorian Studies” 1992, t. 34, nr 3, s. 337. 
Ożywić jej oczy i serce.

(...)

Teraz Febusie daj jej językowi łagodny rozmach

I niech tej jasnej białogłowej determinacja słodko dzwoni.

(...)

Esculapius: Daję ci zdrowie, moja droga.

(...)

Plu. Obiecuje ci bogactwo moja droga.

Bak. Wymyślę coś później najdroższa,

Kiedy wytrzeźwieje.

Venus. Trwałe będą twoje wdzięki.

Momus. Radość będzie przy twoim boku.

Mars. Daję ci stałe zlecenie,

Od jesieni do wiosny ${ }^{24}$.

Pandora zostaje obdarzona wartościami kształtującymi wiktoriański ideał kobiecości: miłością, delikatnością, poezją, zdrowiem, wdziękiem, radością i bogactwem. Jej uformowane ciało nieskażone zostaje jedynie bachusową namiętnością i wolnością, która pozostawała w sprzeczności ze stereotypem doskonałej kobiety. Piękna i wzorcowo ukształtowana Pandora jest również aktorką na usługach Marsa, dla którego ma pracować od marca do października, w miesiącach otwarcia Olympic Theatre. Pandora jest więc jedną z wcieleń Madame Vestris, kobiety stwarzanej przez wzrok widzów, zapisanej ich pragnieniami, formowanej przez normy i uprzedzenia świata sztuki. Była to rola, w której Vestris królowała, zdzierając powłokę fałszywych znaczeń, ukazując siebie jako kobietę wyzwoloną. „Olympic Revels - pisze jeden z recenzentów - rozszalał się jak dziki ogień, nie tylko do czasu opuszczenia kurtyny, lecz do końca sezonu"25.

Ten dziki płomień, o którym pisał recenzent, miał niewątpliwie subwersywny charakter. Pod koniec aktu stworzenia Pandory zazdrosna Junno podarowała jej pasję ciekowości, która u Planchégo najczęściej występuje jako siła uaktywniająca kobiety. Dzięki jej mocy bohaterki mogą przełamać bariery stanowiące o schematyzacji ich wizerunku. Ciekawość Pandory skłania ją do otwarcia skrzyni, czym skazuje ona siebie i świat na życie w grzechu. Bez tego czynu stałaby się jedynie ciałem-ozdobą: „moje bogactwo jest w mojej twarzy" ${ }^{26}$, wpisałaby się w uprzedmiotawiającą, konsumpcyjną wizję kobiecości, tak popularną w dziewiętnastowiecznej Anglii. Stałaby się również ikoną nieszczęśliwego małżeństwa, w którym mężczyzna traktuje żonę jako towar przynoszący s. 49.

${ }^{24}$ J.R. Planché, Olympic Revels [w:] The Extravaganzas of J.R. Planché, t. 1, London 1879,

25 J. Coleman, The Social Status of the Actor, „National Review” 1885, nr 5, s. 20.

26 J.R. Planché, Olympic Revels, dz. cyt., s. 57. 
dochód: „Doskonały biznes, ani dóbr ani pieniędzy;// Rozgryź to - mam plaster miodu bez miodu"27. Ku zaskoczeniu bogów wyłaniająca się z dna skrzyni Nadzieja odwraca losy Pandory oraz funkcje kufra. Otwarcie zła, skosztowanie zakazanego owocu, poddanie się pasji inicjuje nowe, świadome siebie życie. Pandora jako postać mityczna rozpoczyna nowy rozdział życia; Vestris jako Pandora dzieli się zaś zakazanymi owocami z widownią swojego teatru:

Śmiejcie się, wy przychylni bogowie z naszych Olympic Revels,

Wy, radośni eleganci, chodźcie, wygnajcie moje melancholie

Niech moje winogrona nie będą kwaśne, jak te lisa,

Wypełnijcie stałymi klientami wszystkie puszki Pandory ${ }^{28}$.

\section{Ciało zamknięte w słowach. Extravaganze J.R. Planchégo i język subwersywny}

Teatr Madame Vestris sztukami Planchégo łamał schematy dotyczące kobiecości. Owe „melancholie” oraz „winogrona”, które w bajce Ezopa ${ }^{29}$ miały zostać nietknięte przez lisa, gdyż wisiały wysoko poza jego zasięgiem, przez co zostały przez niego skrytykowane i zawistnie wyszydzone, przygotowywały widzów na nowy dialog o istocie kobiecego ciała i pozycji, jaką nadaje mu społeczeństwo. Subwersywność treści była jednak bardzo subtelna, zapisana w języku, pozbawiona obrazoburczej rewolucji, tak znamiennej dla późniejszej groteskowej burleski. Extravaganza jako gatunek literacki i teatralny nie charakteryzuje się jednoznacznymi cechami, sam Planché, będący twórcą tego gatunku w Anglii, używał terminu „extravaganza” wymiennie z „burletta”, „burleska” czy „pantomima” ${ }^{2}$. Brak jasności gatunkowej związany jest przede wszystkim z angielskim prawem rozdzielającym teatry na patentowe, mające licencje dramatyczną, i domy rozrywki, skazane na mniej poważne formy teatralne. Te ostatnie nazywane były w taki sposób, aby autor tekstu i menadżer teatru mogli otrzymać pozwolenie na ich wystawienie. Zebrane w późniejszym czasie sztuki Planchégo wydane zostały pod zbiorczym tytułem Extravaganze, co pozwala nam zrozumieć, iż autor powoli i pod różnymi nazwami stwarzał jeden gatunek teatralny, inspirowany francuską literaturą. Extravaganze, w odróżnieniu od siostrzanych form, miały się

27 Tamże, s. 57.

28 Tamże, s. 60.

29 Ezop, Lis i winogrona [w:] K.I. Gałczyński, Przektady, t. 2, Warszawa 1979, s. 772.

${ }^{30}$ Nawet niektóre tytuły mają dwie nazwy, na przykład J.R. Planché, High, Low, Jack \& The Game, or, The Card Party: A Most Extravagant Extravaganza, or Rum-Antick Burletta, London 1833; w wydaniu zebranym extravaganz Planchégo zaś znajdują się tytuły zawierające wiele określeń, na przykład tenże, Blue Beard; A Grand Musical, Comi-Tragical, Melo-Dramatic, Burlesque Burletta [w:] Extravaganzas of J.R. Planché, dz. cyt., t. 2, London 1979, s. 33-62. 
opierać na złożonych grach słownych, aluzjach, zabawach z współczesnym slangiem i utartymi sformułowaniami językowymi. Łagodne i poetyckie extravaganze, obdarzone niezwykłą siłą ironii, parodii i żartu, obnażały skostniałe normy rzeczywistości, obdzierały z utartych schematów współczesne angielskie znaczenia i wartości. Ich język miał charakter subwersywnego języka poezji, o którym pisała Julia Kristeva, upatrując właśnie w tej formie wypowiedzi literackiej powrotu do sedna tożsamości, matczynego łona, odcinającego się od matrycy znaczeń naddanych ${ }^{31}$. Dramatyczna poezja Planchégo ukazuje mechanizm działania języka, odpowiedzialnego za stwarzanie kobiecości, poddawanie jej ciała binarnemu światopoglądowi. Mistrzowska umiejętność wykładania pięknym słowem surowej nauki była doceniania już przez współczesnych. Znaczące wydaje się to, iż extravaganzę wystawiano podczas świąt Bożego Narodzenia lub Wielkiejnocy. Poetycki świat fantazji, transformacji, językowych zabaw skłaniał się ku karnawałowej potrzebie przedstawienia świata na opak. Zgodnie z Bachtinowską teorią karnawału Planché pozwalał zaistnieć głosowi walczącemu o swój byt; głosowi, który przemawiał przeciwko dominującemu dyskursowi. Ukazywał on prawa, według których nadawane były role płci i odczytywane było kobiece ciało. Jednak, jak zwraca uwagę Robert C. Allen, teatr popularny dziewiętnastego wieku daleki był od rabelaisowskiego karnawału szesnastowiecznej Francji ${ }^{32}$. Karnawał w teatrze wiktoriańskim jawił się jako usankcjonowany, zalegalizowany i podległy politycznym wpływom. Spontaniczność relacji między performerem i widzem, transgresyjność rodzącego się między nimi spektaklu, była instytucjonalna. Groteska i naruszanie sfer tabu nie zagrażało normom społecznym. Umiarkowanie rewolucji inicjowanych przez extravaganze, obwarowanie ich pięknem słowa i ramami teatralnej przestrzeni przyczyniały się do popularności tych form i akceptowalności ich subwersywnych treści. Karnawałowe wywrócenie świata do góry nogami w teatrze Planchégo i Vestris nie było więc groteskowe, nie dotyczyło ukazywania „oddolnych” potrzeb, naruszających tabu; raczej wskazywało na dialogiczność rzeczywistości, na istnienie „ciała społecznego”, które formowane jest według dominujących dyskursów epoki.

W sztuce The Golden Branch ukazana jest dialogiczność brzydoty ciała. Według brutalnego króla-ojca jego syn oraz wybrana dla niego księżniczka są karykaturalnie brzydcy. O ich braku urody świadczy jednak tylko jego słowo oraz portrety odwołujące się do sztuki realistycznej, której język jest względny, co przyznaje sama księżniczka: „Książe Humpty nigdy nie mógłby zdobyć moich względów,// Nawet jeśli byłby w połowie tak brzydki, jak go namalowano"33.

${ }^{31}$ J. Kristeva, Powers of Horror..., dz. cyt., s. 61-63. Więcej na temat języka poetyckiego Kristevej oraz jej „semiologii paragramów” znajdziemy w: A. Dziadek, Od polityki i teorii do literatury. Wokót „Théorie d'ensemble” grupy Tel Quel, „Przestrzenie Teorii” 2002, nr 1, s. 105-117.

32 R.C. Allen, Horrible Prettiness: Burlesque and American Culture, Chapel Hill 1991, s. 36.

33 J.R. Planché, The Golden Branch [w:] The Extravaganzas of J.R. Planché, t. 3, London 1879, s. 194. 
Znając wygląd przeznaczonej sobie osoby tylko ze słów i portretu, książę i księżniczka odmawiają małżeństwa, konsekwencją czego jest ich uwięzienie. W więziennej wieży odnajdują księgę pasterskiej idylli, która dokonuje metamorfozy ich wizerunków - poddaje ciała wybranków działaniom arkadyjskich konwencji. Książę odczytuje siebie na ilustracji według ojcowskich kryteriów jako garbatego elfa, ale księżniczka staje się dla niego aniołem. Podobnie księżniczka w ilustracji swojej osoby nie widzi zmian, jednak książę wydaje się jej pięknym pastuszkiem. Piękno cielesne jest więc kontekstualizowane, odczytywane poprzez medium kulturowe i dominujący język. Ciała dwójki bohaterów ulegają dalszym transformacjom; będąc częścią księgi arkadyjskiej, bohaterowie staną się idyllicznie piękni, ale zaraz potem zamienią się w owady, dzięki transformacyjnej sile pierwiastka zła, typowego dla baśniowej aury świata fantazji. Ich ciała są płynne, same w sobie nie generują wartości estetycznych i etycznych. Przeciwnie, kształtowane są i odbierane na obraz i podobieństwo praw rządzących światem. Dopiero wyzwolona świadomość zatrzyma bohaterów w pożądanej formie, w której umknąć mogą mechanizmom rzeczywistości. Planché wydaje się mówić, iż istnieje jakieś substancjalne „ja”, rozmyte przez niejednoznaczność, transformacyjność i momentalność ciała. „Ja” posiada świadomość i wolę, dążącą do spełnienia, samorealizacji oraz ekspansji własnego terytorium. Wola świadomości może się przeciwstawiać dominującym siłom, oddalać się od afektywnych działań rzeczywistości niezgodnych z pragnieniami. Ponieważ jednak ciało jest w ciągłym ruchu, przyjmując coraz to nowe kształty inskrybowanych treści, to tylko ruchem może wprowadzić tożsamość w nowy obieg. Powtarzalny gest i dialog, wszystko to, co wywołuje poruszanie i transgresyjność, kształtuje ciało oraz świadomość. Dlatego też Planché afirmuje kobiecą ciekawość, która skłania do czynu: w The Golden Branch ciekawość otwiera księgę, w Olympic Revels - skrzynię, w Bluebeard zakazany pokój. Aktywność kobiecych bohaterek jest związana z performatywnością, o której pisze Judith Butler ${ }^{34}$. Performatywność przeczy sztywno uformowanym kulturowym nakazom i schematycznym podejściom, zakładając, iż będąc świadomym płynności swojego ciała i tożsamości, można się uwolnić z ciężaru historii, wyzwolić się $\mathrm{z}$ kulturalnych osądów. Ciało w extravaganzach z jednej strony jest więc niewolnikiem praw, jak ciało księcia i księżniczki w The Golden Branch, niemających wpływu na inskrypcje króla, realizm sztuki czy typowość arkadii. Z drugiej strony ciało zostaje oddane na użytek świadomej osoby, która przyjmie formę zgodnie z własną świadomością wolności wyboru:

Czas nadszedł, aby zatrzymać wasz prywatny spokój,/ Z ignorancją w ciemności warzący zło!/ Robienie z prostych ludzi bestii i brutali,/ duchowi epoki dłużej nie

${ }^{34}$ J. Butler, Uwiktani w pteć. Feminizm i polityka tożsamości, tłum. K. Krasuska, Warszawa 2008, s. 244. 
pasuje./ Waszej ciemnej sztuki gardzi być dłużnikiem/ (...)/ By uszczęśliwić ludzi, obdarza ich mądrością ${ }^{35}$.

Ciała kobiecych bohaterek Planchégo muszą się wyzwolić z nałożonych na nie wizerunków. Transformacje cielesne świadomych siebie kobiecych postaci obserwujemy w wielu jego sztukach. W The Island of Jewels główna bohaterka została oszpecona przez złą wróżkę. Jej groteskowy wygląd uwydatnia wszystko to, co niezgodne było z obowiązującym kanonem piękna. Bohaterka posiada rude włosy, zezowate oczy, szerokie usta, czarne zęby, duży nos i garb. Jej karnawałowa, groteskowa twarz powinna wieścić światu prawdę, zaprzeczać porządkowi i normom kulturowym, stanowiąc krzywe zwierciadło społeczeństwa. Jednak w sztuce Planchégo jej groteskowość zostaje odsunięta, wygnana ze społeczeństwa, potraktowana jako zagrożenie dla ładu ustanowionego przez króla i królową. Nawet dobre cechy bohaterki, które podobnie jak wygląd zostały zapisane na jej ciele przez wróżki, nie zmieniają jej statusu jako osoby Innej:

Przyznaję - mówi król i ojciec dziewczyny - robiły co mogły, miłe stworzenia;/ Jedna dała jej zdrowy rozsądek, inna spryt;/ Dobrą naturę - miłość do prawdy - respekt wobec obowiązków -/ Ale nic aby ułagodzić pragnienie piękna! ${ }^{36}$.

W społeczeństwo wpisuje się zaś egoistyczna i zawistna siostra bohaterki, która odzwierciedla kanony pożądanego wyglądu, reprezentuje świat estetyki i społecznych wizji ciała. Fizyczność obydwu bohaterek zależna jest od odbioru ich przez zgromadzonych wokół królewskiej pary ludzi, żadna z sióstr nie ma wpływu na swój wizerunek i los. Nawet ich imiona wskazują na podporządkowanie ich tożsamości wartościom naddanym: Laidronetta - brzydka i Bellotta - piękna. Sprzeczność estetyki ciała z etyką ich codziennego życia kwestionuje jednak nadane bohaterkom wartości. Względność nazw i cielesnej prawdy powoduje, iż służąca Fidelia widzi Laidronettę jako najpiękniejszą z ludzi. Ona sama zaś mówi: „Przyznaje sama, mamy skłonność do widzenia siebie/ Nie takimi, jakimi jesteśmy, lecz jakimi chcemy być"37. Zła wróżka, odpowiedzialna za szpetny wygląd księżniczki, potwierdza relatywność odczytywania ciała, mówiąc do swojej ofiary: „Mój czar ledwo mógł na ciebie wpłynąć./ Ludzkie oczy jedynie uległy moim magicznym sztuczkom” ${ }^{38}$. Bohaterka nie jest więc brzydka. Prawo ustanowiło jej brzydotę, społeczeństwo zaś uwierzyło dominującej sile. Laidronetta dokonuje transformacji własnej świadomości, odczarowuje siebie we własnych oczach, narzucając na siebie swój własny tekst i udowadnia innym, iż mylnie odczytywali jej ciało.

35 J.R. Planché, The Golden Branch, dz. cyt., s. 221.

${ }^{36}$ Tenże, The Island of Jewels [w:] The Extravaganzas ofJ.R. Planché, t. 4, London 1879, s. 15.

37 Tamże, s. 17.

38 Tamże, s. 36. 


\section{Dialog ciała z teatrem. Extravaganze J.R. Planchégo} na scenie

Kobiece ciało w extravaganzach Planchégo jest tekstem zapisywanym przez sytuacje, kulturę, środowisko, społeczeństwo, historię, prawa, normy i predyspozycje. Samoświadomość, o którą walczy w swych sztukach autor extravaganz, nie posiada narzędzi poznania, jest improwizacją, narracją o sobie. Ponieważ zaś narracja jest negocjacją z otaczającymi źródłami inskrypcji, nie ma także granicy między tym, co wewnętrzne, i tym, co zewnętrzne. Zaprzeczenie kartezjańskiego dualizmu pozwala patrzeć na człowieka jako na ciągłą transformację energii. Taka wizja ciała w teatrze nabiera dodatkowego znaczenia. Zewnętrzne są nie tylko treści, z którymi mierzy się aktor, lecz także kostium i scenografia, które wpływają na postać i aktora oraz kształtują ją. Planché traktował kostium teatralny jako najbardziej namacalny symbol inskrybowanego na ciele tekstu - dramaturg zainicjował nowy ruch w teatrze, oparty na antykwarycznym podejściu do kostiumu i scenerii. Kostium był dla niego czymś więcej niż ubraniem scenicznym, miał wnosić na scenę treści historyczne i świadczyć o autentyczności sztuki. Był sam w sobie tekstem, który nakładał treści na ciało aktora, i podobnie jak ciało stanowił przestrzeń współtworzącą teatr. Traktowany jako wydarzenie, a nie obiekt, wprowadzał wyzwanie dla aktora, nakłaniając do współdziałania i współtworzenia sztuki. Planché napisał kilka encyklopedii poświęconych kostiumom, miał pogłębioną wiedzę na ten temat - nic więc dziwnego, że stroje do jego sztuk były wnikliwie analizowane. Zarówno kostium, jak i scenografia - choć ta ostatnia w mniejszym stopniu, bo zależała od samego pisarza - miały ukazywać polifoniczność ciała, ciągle wsłuchanego w kod kulturowy i historyczny. Aktor poruszał się wśród scenografii (prowokowującej jego ciało do dialogu), nosząc kostium, który narzucał swoje treści. Animacja martwych obiektów, tak znamienna dla baśniowego i mitycznego świata sztuk Planchégo, na scenie odgrywa dodatkową rolę: ukazywała ciało i świadomość w ciągłym ruchu wobec otaczającej rzeczywistości.

W świetle powyższych rozważań warto zwrócić uwagę na cross-dressingowe kostiumy, które na ciało aktorki narzucały nie tylko historyczne treści, ale i męski charakter. W extravaganzach Planchégo często pojawia się motyw cross-dressingu, który obnaża umowność płci oraz wartości wnoszące binarny podział damsko-męski. Zamiany ról damsko-męskich w extravaganzach nie były odbierane jako zagrożenie dla patriarchalnej kultury, gdyż wpisywały się $\mathrm{w}$ długą tradycję umownego transwestytyzmu w teatrze angielskim ${ }^{39}$. Aktorki w męskich obcisłych strojach, odgrywające przede wszystkim bohaterskich

39 J.E. Howard, Cross-Dressing, The Theatre, and Gender Struggle in Early Modern England [w:] Crossing the Stage: Controversies on Cross-Dressing, red. L. Ferris, New York 1993, s. 19. 
młodzieńców, uwydatniały kobiece wdzięki i piękno ciał, których widokiem karmiła się męska widownia. Można rzec za Rolandem Barthes'em, iż była to mała dawka szczepionki zła, jak określa on funkcję striptizu, która miała lokalizować i powstrzymać choroby społeczeństwa, wynikające z tabu cielesności ${ }^{40}$. Jednak akcentowanie sprzeczności między strojem, rolą i ciałem uwidacznia sztuczność podziałów i prowadzi do upłynnienia granic jednolitych wzorców. Tym bardziej że role cross-dressingowe wykonane przez ikonę erotyzmu i symbol kobiecości - Madame wprowadzały do dialogu społecznego alternatywę dla binarnego postrzegania świata. Transwestyzm Vestris wskazywał na możliwość elastyczności ciała, posiadania "trzeciej płci” czy też „trzeciej kategorii”, która daje przestrzeń możliwości. Bycie „trzecim” zaprzecza nie tylko dwoistemu odczytywaniu rzeczywistości, ale także jedności w odczuciu samoświadomości, samowystarczalności i samowiedzy ${ }^{41}$. Kostiumy Vestris uwydatniały jej transformacje cielesne. Role aktorki opierały się na grze między zaprojektowanym ubraniem i samoświadomą kobiecością. Nina Auerbach pisze: „Jej najbardziej ukochanym trikiem było manifestowanie wciąż na nowo i na nowo swojej bezczelnej męskiej natury" ${ }^{\prime 2}$. Metamorfoza aktorki była jeszcze ciekawsza, kiedy dokonywała się na oczach widza. W Fortunio and His Seven Gifted Servants najmłodsza córka mającego tylko żeńskich potomków barona wdziewa męskie szaty, aby wyruszyć na wojnę zamiast ojca. Przeistaczając się w Fortunio, który jest również Myrtiną, odgrywa podwójną rolę do końca sztuki, będąc obiektem westchnień kobiet i mężczyzn ${ }^{43}$. Kiedy zmuszony do demaskacji Fortunio okazuje się córką barona, Król mówi o niej: „piękna, niewinna, nieokreślona ona” ${ }^{44}$. Bohaterka na nowo staje się kobietą, mającą poślubić króla, choć jej dwuznaczność do końca zostaje utrzymana z pełną świadomością niepoprawności podobnego przedstawiania roli płci: „Naszemu szaleństwu pofolgowaliśmy, panowie/ Jednak, nie przestawajcie nas krytykowaćl Świadczyłoby to bowiem o waszym szaleństwie” ${ }^{35}$.

${ }^{40}$ R. Barthes, Mitologie, tłum. A. Dziadek, Warszawa 1957, s. 151.

${ }^{41}$ Zob. M.B. Garber, Vested Interests: Cross-Dressing \& Cultural Anxiety, New York 1992, s. 11.

${ }^{42}$ N. Auerbach, Hellen Terry, Player in Her Time, London 1987, s. 49.

${ }^{43}$ W sztukach J.R. Planchégo odnajdziemy częste nawiązania do sztuk Williama Szekspira. Fortunio and his Seven Gifted Servants fabułą przypomina Wieczór Trzech Króli, choć w tekście znajdziemy także odwołania do słów Hamleta. O licznych aluzjach Planchégo do sztuk Szekspira pisał: J. Richards, The Golden Age of Pantomime: Slapstick, Spectacle and Subversion in Victorian England, London 2015, s. 122.

${ }^{44}$ J.R. Planché, Fortunio and His Seven Gifted Servants [w:] The Extravaganzas of J.R. Planché, dz. cyt, t. 2, London 1879, s. 227.

45 Tamże, s. 228. 


\section{Wnioski. Ciało między przestrzeniami w extravaganzach J.R. Planchégo}

Subwersywność treści extravaganz J.R. Planchégo dotyczy przede wszystkim kobiecego ciała. W jego sztukach ciało kobiece formuje się między przestrzenią widowni, aktora, słowa i teatru. To „ciało-pomiędzy”, które z jednej strony jest obserwowane, z drugiej zaś samo obserwuje, pozostając obszarem zależnym od treści go formujących, polem rozgrywki między dominującym dyskursem a subwersywną świadomością. Kobiece ciało w extravaganzach jest obce w oczach widza, choć nakłada on na nie językowy kod znaczeń w celu identyfikacji swoich pragnień z obrazem przedstawienia. W teatrze Planchégo jest obce również aktorce, która tylko częściowo może zapanować nad ostateczną formą swojego ciała na scenie. Substancja teatru, jaką jest fizyczna materia ciała, okazuje się dynamiczną formą, wynikającą z inskrypcji spojrzeń, treści i atrybutów teatralnej przestrzeni. Sztuki autora extravaganz są dialogiem z patriarchalną wizją binarnego świata, teatr przez nie inicjowany staje się przestrzenią liminalną, która według Charlesa La Shure’a nie jest sferą zepchnięta na margines społeczeństwa, lokuje się raczej w pęknięciach w jednolitym społecznym dyskursie ${ }^{46}$. Z niejednorodności dialogu wiktoriańskiego dotyczącego ciała rodzą się liminalne postacie bohaterek Planchégo. Obdarzone wolnością i naznaczone Innością ciała kobiet extravaganz podejmują dyskusje z zewnętrznym światem i na czas trwania przedstawienia reprezentują ów „moment oddalenia”, o którym pisała Amanda Anderson ${ }^{47}$. Ciało w teatrze Planchégo, będąc wytworem skrzyżowanych ze sobą sił sprawczych, jest namacalnym dowodem na budzącą się do życia nową wiktoriańską kobiecość.

\section{Bibliografia}

Allen R.C., Horrible Prettiness: Burlesque and American Culture, Chapel Hill 1991. Anderson A., The Powers of Distance: Cosmopolitanism and the Cultivation of Detachment, Princeton 2001.

Armstrong N., Desire and Domestic Fiction: A Political History of the Novel, New York 1987.

Auerbach N., Hellen Terry, Player in Her Time, London 1987.

Barthes R., Mitologie, tłum. A. Dziadek, Warszawa 1957.

Buszek M.E., Pin-Up Grrrls: Feminism, Sexuality, Popular Culture, Durham 2006.

${ }^{46}$ Ch. La Shure, What is Liminality?, http://www.liminality.org/about/whatisliminality/, dostęp: 1.07.2017.

47 A. Anderson, dz. cyt., s. 4. 
Butler J., Uwiktani w pteć. Feminizm i polityka tożsamości, tłum. K. Krasuska, Warszawa 2008.

Coleman J., The Social Status of the Actor, „National Review”1885, nr 5.

Coventry P. , Angel in the House, London 1854-1856.

Davidoff L., C. Hall, Family Fortunes: Men and Women of the English Middle Class 1780-1850, New York 1987.

Davis T., Actress as Working Women: Their Social Identity in Victorian Culture, New York 1991.

Dziadek A., Od polityki i teorii do literatury. Wokót „Théorie d'ensemble” grupy Tel Quel, „Przestrzenie Teorii” 2002, nr 1.

Ezop, Lis i winogrona [w:] K.I. Gałczyński, Przektady, t. 2, Warszawa 1979.

Finch C., "Hooked and Buttoned Together": Victorian Underwear and Representations of the Female Body, „Victorian Studies” 1992, t. 34, nr 3.

Gerber M.B., Vested Interests: Cross-Dressing \& Cultural Anxiety, New York 1992.

Howard J.E., Cross-Dressing, The Theatre, and Gender Struggle in Early Modern England [w:] Crossing the Stage: Controversies on Cross-Dressing, red. L. Ferris, New York 1993.

Iwasiów I., Między queer a zwyktością. Pożądanie (na) spektaklu [w:] Inna scena: ciato, pteć, pożądanie. Tożsamość seksualna i tożsamość ptci w polskim dramacie $i$ teatrze, red. A. Adamiecka-Sitek, D. Buchwald, Warszawa 2008.

Jackson R., Victorian Theatre: The Theatre in Its Time, London 1989.

Kristeva J., Powers of Horror: An Essay on Abjection, New York 1982.

La Shure Ch., What is Liminality?, 2005, http:/www.liminality.org/about/whatisliminality/, dostęp: 1.07.2017.

Langland E., Nobody's Angels: Middle-Class Woman and Domestic Ideology in Victorian Culture, London 1995.

Lehmann H.-T., Postdramatic Theatre, New York 2006.

Macintosh F., Medea Transposed: Burlesque and Gender on the Mid-Victorian Stage [w:] Medea in Performance 1500-2000, red. E. Hall, F. Macintosh, O. Taplin, Oxford 2000.

Mayer D., Encountering Melodrama [w:] The Cambridge Companion to Victorian and Edwardian Theatre, red. K. Powell, Cambridge 2004.

Mielewska-Miachaś A., Wiktoriański modus melodramatyczny $w$ kontekście teatru masowego epoki [w:] Teatr masowy - teatr dla mas, red. M. Leyko, Łódź 2011.

Moody J., Illusions of Authorship [w:] Women and Playwriting in Nineteenth-Century Britain, red. T.C Davis, E. Donkin, Cambridge 1992.

Planché J.R., Blue Beard; A Grand Musical, Comi-Tragical, Melo-Dramatic, Burlesque Burletta [w:] Extravaganzas of J.R. Planché, t. 2, London 1979.

Planché J.R., Fortunio and His Seven Gifted Servants [w:] The Extravaganzas of J.R. Planché, t. 2, London 1879.

Planché J.R., The Golden Branch [w:] The Extravaganzas of J.R. Planché, t. 3, London 1879. 
Planché J.R., High, Low, Jack \& The Game, or, The Card Party: A Most Extravagant Extravaganza, or Rum-Antick Burletta, London 1833.

Planché J.R., The Island of Jewels [w:] The Extravaganzas of J.R. Planché, t. 4, London 1879.

Planché J.R., Olympic Revels [w:] The Extravaganzas of J.R. Planché, t. 1, London 1879.

Poon A., Enacting Englishness in Victorian Period: Colonialism and Politics of Performance, New York 2008.

Poovey M., Uneven Developments: The Ideological Work of Gender in Mid-Victorian England, Chicago 1988.

Richards J., The Golden Age of Pantomime: Slapstick, Spectacle and Subversion in Victorian England, London 2015.

Rodosthenous G. Introduction [w:] Theatre as Voyeurism: The Pleasure of Watching, red. G. Rodostenous, London 2015.

Scott J.W., Gender: A Useful Category of Historical Analysis, „American Historical Review” 1986, nr 91 (5).

"The Times", Beauty and the Beast, 13 April 1841.

Voskuil L.M., Acting Naturally: Victorian Theatricality and Authenticity, Charlottesville 2004.

Williams C.J., Madame Vestris: A Theatrical Biography, London 1973.

Williams G.J., Our Moonlight Revels: A Midsummer Night's Dream in the Theatre, Iowa City 1997.

Woolf V., Praca zawodowa kobiet [w:] tejże, Eseje wybrane, wybór, oprac. M. Heydel, R. Sendyka, tłum. M. Heydel, Kraków 2015. 